\title{
HUBUNGAN MOTIVASI PERAWAT DAN GAYA KEPEMIMPINAN DENGAN PERILAKU PERAWAT DALAM PEMBUANGAN SAMPAH MEDIS BENDA TAJAM DI RSUD DR.A.DADI TJOKRODIPO KOTA BANDAR LAMPUNG
}

\author{
Rike Saputra ${ }^{1}$, M. Arifki Zainaro ${ }^{2^{*}}$, M. Ricko Gunawan ${ }^{2}$ \\ ${ }^{1}$ Mahasiswa Program S1 Keperawatan Universitas Malahayati \\ Email : rikesptr@gmail.com \\ 2Dosen Program DIII Keperawatan Universitas Malahayati \\ Email : m.arifkiz@yahoo.com \\ ${ }^{3}$ Dosen Program S1 Keperawatan Universitas Malahayati \\ Email :muhrickogunawan@gmail.com
}

\section{ABSTRACT: THE CORRELATIONS OF NURSE'S MOTIVATION AND LEADERSHIP STYLE TO NURSE'S BEHAVIOR IN SHARP MEDICAL WASTE DISPOSAL IN DR. A. DADI TJOKRODIPO PUBLIC HOSPITALIN BANDAR LAMPUNG}

Introduction: sharp medical waste is not only able to cause scratch and stab wounds but also to infect wounds when they are contaminated by pathogen. A pre-survey result done by the researcher in wards of dr. A. Dadi Tjokrodipo at 20 January 2019 to 10 nurses concerning activities of nursing care and medicla waste management including needle, syringe, and bandage that were disposed without sorting.

Purpose: the purpose of this research was to find out the correlations of nurse's motivation and leadership style to nurse's behavior in sharp medical waste disposal in dr. A. Dadi Tjokrodipo public hospital in Bandar Lampung.

Method: this was a quantitative analytic survey research by using cross sectional approach and it was conducted in dr. A. Dadi Tjokrodipo public hospital from March to April 2019. Population was all nurses and samples were of total sampling. Data were collected by using questionnaires and analyzed by using univariate (frequency distribution) and bivariate (chi square test) analyses.

Result: there were 31 respondents $(54.4 \%)$ with poor medical waste littering behavior, 34 respondents (59.6\%) with low motivation, and 29 respondents (50.9\%) with bad leadership style. There were correlations of nurse's behavior ( $p$-value 0.000; OR 11.70) and leadership style ( $p$-value 0.012: OR 4.725) to sharp medical waste disposal in dr. A. Dadi Tjokrodipo public hospital in Bandar Lampung in 2019.

Conclusion: there were correlations of nurse's motivation and leadership style to nurse's behavior in littering sharp medical waste in dr. A. Dadi Tjokrodipo public hospital in Bandar Lampung in 2019. The researcher expects nurse's motivation improvement concerning medical waste disposal by joining training about effects of improper sharp medical waste disposal.

Keywords : motivation, leadership style, nurse's behavior, medical waste 
INTISARI: HUBUNGAN MOTIVASI PERAWAT DAN GAYA KEPEMIMPINAN DENGAN PERILAKU PERAWAT DALAM PEMBUANGAN SAMPAH MEDIS BENDA TAJAM DI RSUD DR.A.DADI TJOKRODIPO KOTA BANDAR LAMPUNG

Latar Belakang: Sampah medis benda tajam dapat menyebabkan luka gores maupun luka tusuk tetapi juga menginfeksi luka jika terkontaminasi pathogen. Hasil pra survey yang dilakukan peneliti pada bangsal rawat inap di RSUD Dr.A.Dadi Tjokrodipo pada tanggal 20 januari 2019 kepada 10 perawat melalui aktivitas asuhan keperawatan dan pengelolaan sampah medis, jarum, spuit, perban dibuang tanpa dipisahkan terlebih dahulu.

Tujuan: diketahui hubungan motivasi dan gaya kepemimpinan dengan perilaku perawat dalam pembuangan sampah medis benda tajam di RSUD Dr. A. Dadi Tjokrodipo Kota Bandar Lampung.

Metode Penelitian : Jenis penelitian kuantitatif, rancangan penelitian survei analitik dengan pendekatan cross sectional telah dilakukan di RSUD Dr. A. Dadi Tjokrodipo Kota Bandar Lampung bulan Maret-April 2019. Populasi seluruh perawat dengan pengambilan sampel secara Total sampling. pengambilan data menggunakan kuesioner yang dibagikan ke responden. Analisis data secara univariat (distribusi frekuensi) dan bivariat (chi square).

Hasil : Diketahui perilaku pembuangan sampah tajam, sebanyak 31 (54,4\%) responden yang tidak baik, sebanyak $34(59,6 \%)$ responden motivasi kurang kuat, sebanyak 29 (50,9\%) responden gaya kepemimpinan kurang baik, Ada hubungan motivasi dengan perilaku perawat dalam pembuangan sampah medis benda tajam ( $p$-value $=0,000$ OR 11,700), Ada hubungan gaya kepemimpinan dengan perilaku perawat dalam pembuangan sampah medis benda tajam di RSUD Dr. A. Dadi Tjokrodipo Kota Bandar Lampung tahun 2019 ( $p$-value = 0,012 OR 4,725.

Kesimpulan : Ada hubungan motivasi dan kepemimpinan dengan perilaku perawat dalam pembuangan sampah medis benda tajam dengan perilaku perawat dalam pembuangan sampah medis benda tajam di RSUD Dr. A. Dadi Tjokrodipo Kota Bandar Lampung tahun 2019. Peningkatan motivasi perawat terkait dengan pembuangan samapah, dengan mengikutsertakan pelatihan yang berhubungan dengan dampak dari sampah medis tajam yang tidak dikelola dengan baik

Kata kunci : motivasi, gaya kepemimpinan, perilaku perawat, sampah medis

\section{PENDAHULUAN}

Program Indonesia Sehat merupakan salah satu program Nawa Cita, yaitu Meningkatkan Kualitas Hidup Manusia Indonesia dimana Program ini didukung oleh program sektoral lainnya yaitu Program Indonesia Pintar, Program Indonesia Kerja, dan Program Indonesia Sejahtera. Program Indonesia Sehat menjadi program utama Pembangunan Kesehatan yang pencapaiannya melalui
Rencana Strategis Kementerian Kesehatan. (Kemenkes RI, 2016)

World Health Organization (WHO, 2016) melaporkan limbah Rumah Sakit yang dihasilkan layanan kesehatan (rumah sakit) hampir $80 \%$ berupa limbah umum dan 20\% berupa limbah bahan berbahaya yang mungkin menular, beracun atau radioaktif. Sebesar $15 \%$ dari limbah yang dihasilkan layanan kesehatan merupakan limbah infeksius atau limbah jaringan tubuh, limbah benda tajam 
sebesar 1\%, limbah kimia dan farmasi 3\%, dan limbah genotoksik dan radioaktif sebesar $1 \%$. Negara maju menghasilkan 0,5 kg limbah berbahaya per tempat tidur rumah sakit per hari. Rumah sakit dapat dianggap sebagai mata rantai penyebaran penyakit menular karena sampah menjadi tempat berkembang biaknya mikroorganisme penyebab penyakit dan sarang serangga serta tikus. Di samping itu kadang-kadang dapat mengandung bahan kimia beracun dan benda-benda tajam yang dapat menimbulkan penyakit atau cidera (Djuhaeni, 2015).

World Health Organization (WHO) tahun 2015 mencatat kasus infeksi akibat tusukan jarum yang terkontaminasi diperkirakan terinfeksi virus Hepatitis B sebanyak 21 juta (32\% dari seluruh infeksi baru), (2) terinfeksi virus Hepatitis C sebanyak 2 juta (40\% dari seluruh infeksi baru), (3) terinfeksi virus HIV sebanyak 260 ribu (5\% dari seluruh infeksi baru). Pada tahun 2016, hasil penilaian yang dilakukan WHO di 22 negara-negara berkembang menunjukkan bahwa proporsi fasilitas layanan kesehatan yang tidak menggunakan metode pembuangan sampah yang tepat meningkat dari $18 \%$ menjadi $64 \%$ (WHO, 2017).

Sebuah laporan yang diajukan oleh US Environmental Protection Agency di depan kongres Amerika menyajikan perkiraan kasus infeksi Hepatitis B (HBV) akibat cedera oleh benda tajam di kalangan tenaga medis dan pengelolaan sampah rumah sakit. Jumlah kasus infeksi HBV per-tahun di AS akibat pajanan sampah rumah sakit adalah sekitar 162321 kasus dari jumlah total pertahun yang mencapai 300.000 kasus. Pada fasilitas layanan kesehatan dimanapun, perawat dan tenaga kebersihan merupakan kelompok utama yang berisiko mengalami cedera, jumlah yang bermakna justru berasal dari luka teriris dan tertusuk limbah benda tajameeee (Pruss dkk, 2015).

Sampah medis benda tajam dapat menyebabkan luka gores maupun luka tusuk tetapi juga menginfeksi luka jika terkontaminasi patogen. Karena memiliki potensi cedera dan menularkan penyakit, benda tajam termasuk dalam kelompok sampah yang sangat berbahaya. Infeksi yang ditularkan melalui subkutan lewat agent penyebab penyakit. Jarum suntik merupakan bagian yang penting dalam sampah medis benda tajam dan berbahaya karena sering terkontaminasi darah pasien (Pruss dkk, 2015).

Perawat lebih banyak berperan dalam melakukan tindakan pelayanan keperawatan kepada pasien, kemungkinan besar perawatlah yang pertama kali berperan apakah sampah medis sudah dibuang ke tempat yang aman sebelum di kumpulkan dan diangkut ke tempat pembuangan akhir yakni incinerator oleh petugas pengangkut sampah rumah sakit (Lambogia, 2016). Untuk memotivasi seorang perawat khususnya dalam penanganan sampah medis selain kesadaran dari orang itu sendiri, perlu orang lain yang memberi motivasi karena dengan kehadiran orang lain akan semakin meningkatkan motivasi dalam diri perawat seperti kepemimpinan (Zainaro, 2017). Gaya kepemimpinan dapat mempengaruhi bagaimana sistematis manajemen kepemimpinan menuju ke arah kualitas kinerja yang bermutu (Haeranti, 2018).

Penelitian dengan judul pengaruh motivasi kerja terhadap kinerja perawat pelaksana di Ruang Rawat Inap RSUD Alimuddin Umar Kabupaten Lampung Barat tahun 2017 didapati sebagian besar 
motivasi kerja perawat pelaksana di Ruang Rawat Inap RSUD Alimuddin Umar Kabupaten Lampung Barat kurang baik yaitu sebanyak 32 orang (53,3\%) (Zainaro, 2017). Hasil penelitian dengan judul hubungan motivasi perawat dan gaya kepemimpinan terhadap ronde keperawatan diruang rawat inap bedah RSUD Raden Mattaher Jambi menunjukkan bahwa dari 38 responden, $55,3 \%$ memiliki motivasi rendah, $71,1 \%$ dengan gaya kepemimpinan baik (Zainaro, 2018). Hasil penelitian diketahui terdapat hubungan gaya kepemimpinan kepala ruangan dengan kinerja perawat pelaksana di ruang rawat inap RSUD Polewali Mandar ( $p=$ 0,002) (Haeranti, 2018).

Sub instalasi sanitasi Dr.A.Dadi Tjokrodipo Kota Bandar Lampung membuat SOP (Prosedur Tetap) Nomor 29/1NOS/XI/2015 mengenai pemisahan sampah. Petugas kebersihan melapisi bagian dalam tempat sampah dengan kantong plastik sesuai jenisnya, yaitu: (1) kantong plastik kuning untuk sampah medis umum (non sitostatik, non radioaktif, non suntik bekas), (2) kantong plastik hitam untuk sampah non medis, dan (3) untuk sampah medis bekas suntik dimasukan ke dalam kotak safetybox, namun beradasarkan hasil pengamatan, SOP tersebut belum dijalankan dengan sepenuhnya. Hal ini di karenakan pelatihan keselamatan kerja kepada tenaga keperawatan belum di lakukan secara paripurna dan terjadwal, sehingga keterampilan dan kebiasaan serta sikap perawat terhadap praktik keselamatan kerja belum dilaksanakan maksimal.

Dr. A. Dadi Tjokrodipo Kota Bandar Lampung merupakan salah satu rumah sakit pemerintah yang memiliki tenaga keperawatan 147 yang terbagi antara di seluruh ruangan tindakan rawat inap maupun poliklinik dan memberikan pelayanan kesehatan kepada masyarakat secara professional. Pelayanan kesehatan kepada masyarkat ini tentunya harus didukung oleh tenaga kesehatan yang bermutu khususnya perilaku tenaga kesehatan dalam penelitian ini perilaku perawat dalam pengelolaan sampah medis. Pengelolaan sampah medis di rumah sakit mengacu pada konsep pengelolaan lingkungan sebagai sebuah sistem dengan berbagai proses manajemen didalamnya yang dikenal sebagai sistem manajemen lingkungan.

Hasil pra survey yang dilakukan peneliti pada bangsal rawat inap di RSUD Dr.A.Dadi Tjokrodipo pada tanggal 20 januari 2019 kepada 10 perawat melalui aktivitas asuhan keperawatan dan pengelolaan sampah medis, jarum, spuit, perban dibuang tanpa dipisahkan terlebih dahulu. Terlihat 8 perawat $(80 \%)$ melakukan pembuangan sampah tidak memperhatikan kebersihan tangan perawat seperti menggunakan sarung tangan dan mencuci tangan setelah membuang sampah, cairan infus atau darah yang berada di kantong plastik berceceran. plastik bekas pembungkus makanan tercampur dengan plabot bekas infuse. Dari hal tersebut di atas, kemungkinan besar perawat yang pertama kali berperan apakah limbah medis padat akan berada pada tempat yang aman atau tidak, sebelum diangkut ketempat pembuangan akhir yakni insinerator oleh petugas pengangkut limbah dari rumah sakit.

Pelaksanaan pengelolaan sampah medis benda tajam di Dr.A.Dadi Tjokrodipo Kota Bandar Lampung masih belum dilaksanakan sesuai prosedur. Hal ini menyebabkan jarum menembus plastik dan limbah cair seperti cairan infus atau darah yang berada 
di kantong plastik berceceran. Masalah ini harus segera diatasi karena dapat menyebabkan risiko terkena penyakit dan cedera (tertusuk jarum) terutama pada petugas kebersihan. Petugas kebersihan mengangkut sampah medis setiap pagi menggunakan trolly khusus. Sampah medis benda tajam kemudian dibawa untuk ditimbang dan dimasukan ke dalam insinerator untuk dimusnahkan. Berdasarkan hasil wawancara diketahui bahwa kepala ruangan belum pernah memberikan funisment terhadapa perawat yang membuang sampah tajam bukan ketempatnya.

Melalui hasil analisis sementara didapatkan bahwa penyebab utama produktifitas dan kinerja perawat rendah pada perilaku pembuangan sampah medis tajam ternyata terletak pada orangorangnya, bukan pada peralatan kerja yang kurang baik. Rendahnya kinerja perawat diduga terletak pada kemampuan kerja perawat dan motivasi kerja perawat tersebut. Setelah dilakukan observasi ke ruangan didapatkan hasil sementara bahwa sebenarnya kemampuan kerja perawat cukup tinggi, tetapi motivasi kerja perawatnya yang rendah serta gaya kepemimpinan yang kurang pas pada ruangan. Dengan demikian dapat dikatakan rendahnya kinerja perawat disebabkan karena rendahnya faktor motivasi kerja perawat itu sendiri dan gaya kepemimpinan di ruangan.

Berdasarkan

masalah tersebut di atas maka peneliti tertarik untuk meneliti lebih jauh mengenai hubungan motivasi dan gaya kepemimpinan dengan perilaku perawat dalam pembuangan sampah medis benda tajam di RSUD Dr. A. Dadi Tjokrodipo Kota Bandar Lampung.

\section{METODOLOGI PENELITIAN}

Jenis penelitian kuantitatif Penelitian ini bersifat deskriptif analitik, pendekatan cross sectional Populasi perawat pelaksana RSUD DR. A. Dadi Tjokrodipo Kota Bandar Lampung di ruang rawat inap E1, E2, E3 dan E4 sebanyak 57 orang perawat. Jumlah sampel dalam penelitian ini sebanyak 57 responden, teknik sampling yang digunakan adalah dengan cara teknik total sampling. Penelitian ini telah dilakukan Tanggal 21 Juni 21 Juli 2019 di RSUD DR. A. Dadi Tjokrodipo Kota Bandar Lampung. Alat ukur/Instrumen berupa kuesioner (angket tertutup) Peneliti menggunakan kuesioner yang sudah pernah dilakukan uji validitas dan reliabilitas, sehingga peneliti tidak melakukan uji validitas dan reliabilitas lagi. Instrumen yang digunakan merupakan instrumen dari penelitian: Mila Triana Sari (2009) hubungan budaya organisasi dan gaya kepemimpinan kepala ruangan dengan kinerja perawat pelaksana di ruang rawat inap rumah sakit daerah raden mattaher jambi, budaya organisasi dengan nilai $u j i \quad r=0,947$ dan gaya kepemimpinan dengan nilai uji $r=$ 0,904 , kinerja dengan nilai $r=$ 0.923, Ridwan, Lutfi Fauji (2013), dengan nilai uji $r=0,863$. Sri Puspan Dari Harahap (2017) dengan nilai uji $r=0,934$. Analisis data univariat dan bivariat (chi square) dengan aplikasi yang digunakan SPSS versi 20. 
HASIL PENELITIAN DAN PEMBAHASAN

Analisis Univariat

Distribusi frekuensi perilaku perawat dalam pembuangan sampah medis benda tajam, motivasi dan gaya kepemimpinan

Perilaku perawat pembuangan sampah medis benda tajam

Tidak baik

Baik

Motivasi

Kurang kuat

Kuat

Gaya kepemimpinan

Kurang baik

\begin{tabular}{cc}
\hline Frekuensi & Persentase $(\%)$ \\
31 & 54,4 \\
26 & 45,6 \\
Frekuensi & Persentase (\%) \\
34 & 59,6 \\
23 & 40,4 \\
Frekuensi & Persentase $(\%)$ \\
29 & 50,9 \\
28 & 49,1 \\
57 & 100.0 \\
\hline
\end{tabular}

Berdasarkan tabel, diketahui dari 57 responden, sebanyak 31 (54,4\%) responden pembuangan sampah medis benda tajam kurang baik dan sebanyak $26(45,6 \%)$ responden yang baik, sehingga dapat disimpulkan bahwa sebagian besar perilaku perawat dalam pembuangan sampah medis benda tajam kurang baik. Berdasarkan tabel, diketahui dari 57 responden, sebanyak $34 \quad(59,6 \%)$ responden motivasi kurang kuat dan sebanyak $23 \quad(40,4 \%)$ responden motivasi kuat, sehingga dapat disimpulkan bahwa sebagian besar motivasi perawat kurang kuat. Berdasarkan tabel, diketahui dari 57 responden, sebanyak 29 (50,9\%) responden mengungkapkan bahwa gaya kepemimpinan kurang baik dan sebanyak $28 \quad(49,1 \%)$ responden mengungkapkan bahwa gaya kepemimpinan baik, sehingga dapat disimpulkan bahwa sebagian besar perawat mengungkapkan bahwa gaya kepemimpinan di rumah sakit kurang baik.

\section{Analisis bivariat}

Hubungan motivasi dengan perilaku perawat dalam pembuangan sampah medis benda tajam di RSUD Dr. A. Dadi Tjokrodipo Kota Bandar Lampung.

\begin{tabular}{|c|c|c|c|c|c|c|c|c|}
\hline \multirow{3}{*}{ Motivasi } & \multicolumn{4}{|c|}{$\begin{array}{c}\text { Perilaku pembuangan } \\
\text { sampah tajam }\end{array}$} & \multirow{3}{*}{$\mathrm{N}$} & \multirow{3}{*}{$\%$} & \multirow{3}{*}{$\begin{array}{c}p- \\
\text { value }\end{array}$} & \multirow{3}{*}{ OR } \\
\hline & \multicolumn{2}{|c|}{ Tidak baik } & \multicolumn{2}{|c|}{ Baik } & & & & \\
\hline & $f$ & $\%$ & $f$ & $\%$ & & & & \\
\hline Kurang kuat & 26 & 76,5 & 8 & 23,5 & 34 & 100,0 & & 11,700 \\
\hline Kuat & 5 & 21,7 & 18 & 78,3 & 23 & 100,0 & 0,001 & $(3,290-$ \\
\hline Total & 31 & 54,4 & 26 & 45,6 & 57 & 100,0 & & $41,608)$ \\
\hline
\end{tabular}

Berdasarkan Tabel dapat diketahui dari 34 responden dengan motivasi kurang kuat, sebanyak 26 $(76,5 \%)$ responden perilaku pembuangan sampah tajam tidak baik dan sebanyak $8(23,5 \%)$ responden perilaku pembuangan sampah tajam baik. Dari 23 responden dengan motivasi kuat, sebanyak $5 \quad(21,7 \%)$ responden perilaku pembuangan sampah tajam tidak baik dan sebanyak 18 (78,3\%) 
responden perilaku pembuangan sampah tajam baik. Hasil uji statistik diperoleh $p$-value $=0,001$ yang berarti $<a(0,05)$, maka dapat disimpulkan bahwa ada hubungan motivasi dengan perilaku perawat dalam pembuangan sampah medis benda tajam di RSUD Dr. A. Dadi
Tjokrodipo Kota Bandar Lampung tahun 2019, dengan nilai OR 11,700 berarti responden dengan motivasi kurang kuat memiliki risiko 11 kali lebih besar perilaku pembuangan sampah medis benda tajam tidak baik jika dibandingkan dengan responden dengan motivasi kuat.

Hubungan gaya kepemimpinan dengan perilaku perawat dalam pembuangan sampah medis benda tajam di RSUD Dr. A. Dadi Tjokrodipo Kota Bandar Lampun.

\begin{tabular}{|c|c|c|c|c|c|c|c|c|}
\hline \multirow[b]{2}{*}{$\begin{array}{l}\text { Gaya } \\
\text { kepemimpinan }\end{array}$} & \multicolumn{4}{|c|}{$\begin{array}{l}\text { Perilaku pembuangan } \\
\text { sampah tajam }\end{array}$} & \multirow[b]{2}{*}{$\mathrm{N}$} & \multirow[b]{2}{*}{$\%$} & \multirow[b]{2}{*}{$\begin{array}{c}p- \\
\text { value }\end{array}$} & \multirow[b]{2}{*}{ OR } \\
\hline & & $\begin{array}{l}\text { samp } \\
\text { k baik }\end{array}$ & & $\begin{array}{l}\text { maik } \\
\text { Baik }\end{array}$ & & & & \\
\hline Kurang baik & 21 & 72,4 & 8 & 27,6 & 29 & 100,0 & & 4,725 \\
\hline Baik & 10 & 35,7 & 18 & 64,3 & 28 & 100,0 & 0,012 & $(1,537-$ \\
\hline Total & 31 & 54,4 & 26 & 45,6 & 57 & 100,0 & & $14,522)$ \\
\hline
\end{tabular}

Berdasarkan Tabel dapat diketahui dari 29 responden dengan gaya kepemimpinan kurang baik, sebanyak $21 \quad(72,4 \%)$ responden perilaku pembuangan sampah tajam tidak baik dan sebanyak $8(27,6 \%)$ responden perilaku pembuangan sampah tajam baik. Dari 28 responden dengan gaya kepemimpinan baik, sebanyak 10 $(35,7 \%)$ responden perilaku pembuangan sampah tajam tidak baik dan sebanyak $18 \quad(64,3 \%)$ responden perilaku pembuangan sampah tajam baik. Hasil uji statistik diperoleh $p$-value $=0,012$ yang

\section{PEMBAHASAN}

$\begin{array}{llr}\text { Hubungan motivasi } & \begin{array}{r}\text { dengan } \\ \text { perilaku }\end{array} \\ \text { perawat }\end{array}$
pembuangan sampah medis benda tajam di RSUD Dr. A. Dadi Tjokrodipo Kota Bandar Lampung tahun 2019.

Menurut pendapat peneliti dari 23 responden dengan motivasi kuat dan yang memiliki perilaku pembuangan sampah tajam baik sebanyak $18(78,3 \%)$ orang, menurut

\begin{abstract}
berarti <a, maka dapat disimpulkan bahwa ada hubungan gaya kepemimpinan dengan perilaku perawat dalam pembuangan sampah medis benda tajam di RSUD Dr. A. Dadi Tjokrodipo Kota Bandar Lampung tahun 2019, dengan nilai OR 4,725 berarti responden yang merasakan gaya kepemimpinan kurang baik memiliki risiko 4,7 kali lebih besar perilaku pembuangan sampah medis benda tajam tidak baik jika dibandingkan dengan responden yang merasakan gaya kepemimpinan baik.
\end{abstract}

pendapat peneliti tingginya motivasi kerja tenaga perawatan di Rumah Sakit dipengaruhi oleh adanya penghargaan yang diberikan dari pimpinan dimana perawat merasa adanya perhatian dari atasan untuk melaksanakan proses keperawatan lebih baik. Kondisi pekerjaan yang menyenangkan dirasakan oleh tenaga perawatan juga dapat mempengaruhi motivasi tenaga perawatan. Hubungan kerja antara teman sejawat dan atasan yang 
terjalin harmonis dan rasa kekeluargaan yang tinggi, kondisi lingkungan kerja yang aman dan nyaman sehingga tenaga perawatan bekerja tanpa ada gangguan atau masalah. Adanya supervisi yaitu pengawasan atau monitoring yang dilakukan secara berkala oleh kepala ketenaga perawatan kepada tenaga perawatan juga harus dilakukan. Adanya supervisi ini diharapkan membuat tenaga perawatan berusaha untuk melakukan tindakan keperawatan sesuai dengan prosedur dan asuhan keperawatan. Adanya promosi pekerjaan bagi tenaga perawatan yang memiliki prestasi salah satunya perilaku pembuangan sampah tajam yang baik. Motivasi yang kuat juga berpengaruh pada rasa tanggung jawab yang dimiliki oleh tenaga perawatan, sehingga setiap melakukan tindakan asuhan keperawatan mereka benar-benar penuh rasa tanggung jawab. Adanya pengembangan diri, yaitu tenaga perawatan mendapatkan kesempatan untuk kemajuan dalam pekerjaan, seperti mengikuti pelatihan, seminar-seminar dan menambah ilmu pendidikan dalam bidang keperawatan.

Adapun sebanyak $5(21,7 \%)$ responden dengan motivasi kuat namun memiliki perilaku pembuangan sampah tajam tidak baik seperti perawat tidak meletakkan tempat sampah infeksius/sharps box pada lokasi yang mudah dilihat,dijangkau dan aman, perawat tidak menghindarkan meremas/menekan kantong plastik kuning yang sudah terisi agar tidak terkena benda tajam perilaku - perilaku ini yang terkesan sepele namun sebenarnya merupakan perilaku dalam pengelolaan sampah tajam, hal ini kemungkinan bisa terjadi karena perawat terburu-buru dalam melakukan kegiatan keperawatan sehingga terkadang reflek untuk meletakkan barang dibukan tempatnya.

Menurut penelitian berdasarkan hasil penelitian diketahui dari 34 responden dengan motivasi kurang kuat, sebanyak 8 $(23,5 \%)$ responden yang memiliki perilaku pembuangan sampah tajam baik hal ini karena perawat memiliki pengetahuan / keterampilan yang baik dalam pengelolaan sampah tajam. dan sebanyak $26 \quad(76,5 \%)$ responden perilaku pembuangan sampah tajam tidak baik, dimungkinkan kurangnya komunikasi antara atasan dan perawat, kompensasi yang diberikan tidak sesuai atau fasilitas yang tidak lengkap sehingga perilaku pembuangan sampah tajam yang terlihat masih kurang baik menurut pendapat peneliti banyak hal yang mempengaruhi motivasi yang kurang kuat pada seorang pegawai seperti kepuasan kerja, system penghargaan, konflik yang ada pada diri perawat itu sendiri sehingga mempengaruhi motivasi kerja dan perilaku pembuangan sampah tajam dari perawat. Menurut peneliti seseorang yang memiliki motivasi kerja tinggi akan bekerja dengan baik, mempunyai rasa tanggung jawab dengan tugas yang diberikan dan selalu berusaha untuk menghasilkan prestasi kerja. Hal tersebut dapat dipahami karena motivasi kerja merupakan faktor yang penting bagi tenaga perawatan untuk menjalankan tugas - tugas yang menjadi tanggung jawab tenaga perawatan. Tanpa adanya motivasi kerja, pekerjaan tidak akan dapat berjalan dengan baik. Apabila motivasi kerja tenaga perawatan tinggi, maka tenaga perawatan dapat bekerja secara maksimal sehingga dapat menghasilkan perilaku pembuangan sampah tajam yang baik pula. Motivasi dapat ditingkatkan salah 
satunya dengan pemberian penghargaan kepada tenaga perawatan yang menunjukkan perilaku pembuangan sampah tajam yang baik, dimana pihak rumah sakit dapat memberikan penilaian yang dilakukan oleh bagian kepegawaian dalam menilai kinerja masing - masing tenaga keperawatan. Selain itu rumah sakit dapat melakukan refreshing bagi karyawan sehingga karyawan tidak jenuh Dengan rutinitas yang dilakukan

Hubungan gaya kepemimpinan dengan perilaku perawat dalam pembuangan sampah medis benda tajam di RSUD Dr. A. Dadi Tjokrodipo Kota Bandar Lampung tahun 2019.

Menurut pendapat peneliti berdasarkan hasil penelitian diketahui 28 responden yang mengungkapkan gaya kepemimpinan baik, sebanyak $10 \quad(35,7 \%)$ responden perilaku pembuangan sampah tajam tidak baik menurut pendapat peneliti penataan lingkungan kerja yang kondusif perlu diciptakan agar tenaga perawatan dapat bekerja secara efektif dan efisien. Menciptakan suasana kerja yang dapat mendorong tenaga perawatan untuk melakukan yang terbaik, diperlukan seorang pemimpin. Pemimpin tersebut harus mempunyai kemampuan untuk memahami bahwa seseorang memiliki motivasi yang berbedabeda. Pemimpin yang baik mampu menentukan gaya kepemimpinan yang tepat dalam memimpin bawahannya dengan memperhatikan karakteristik bawahan dan visi misi organisasi yang hendak dicapai. Pemimpin yang kurang baik, yang tidak dapat memilih gaya kepemimpinan yang tepat, tidak memiliki kemampuan yang memadai, tidak menguasai kewenangan yang dimiliki dan tidak dapat mencipatakan situasi kerja yang menyenangkan tentu akan berimbas kepada perilaku pembuangan sampah tajam bawahan yang kurang baik

Pada hasil penelitian diketahui sebanyak $18 \quad(64,3 \%)$ perilaku pembuangan sampah tajam kurang baik dimungkinkan kurangnya tanggung jawab dalm pekerjaan sesuai dengan standar operasioanl prosedur (SOP) di tempat kerja, motivasi diri / kesadaran diri yang kurang dalm mencapai tujuan atau kurangnya kemampuan /pengalaman/ keahlian dalam melakukan pekerjaan. Oleh karena itu sangat dibutuhkan pemimpin (kepala ruangan) yang siap menghadapi kondisi kritis, sehingga pemimpin (kepala ruangan) ruang tenaga perawatan di rumah sakit betul-betul telah disiapkan baik fisik maupun mental. Persiapan tersebut secara tidak langsung diproses dari pengalaman kerja yang bertahun-tahun dan bekal pengetahuan melalui pelatihan. Dengan demikian kepala ruangan sebagai manajer tingkat bawah dan sebagai individu memiliki sifat dasar dan kepribadian sehingga memiliki kecendrungan karakteristik tersendiri, namun dengan mempelajari perilaku mampu menerapkan perilaku kepemimpinan yang efektif dan mampu memahami karakterisitik dari masing-masing individu.

Sedangkan dari 29 responden dengan gaya kepemimpinan kurang baik, sebanyak $21 \quad(72,4 \%)$ responden perilaku pembuangan sampah tajam baik hal ini dimungkinkan karena responden dalam bekerja tidak hanya loyal kepada pimpinan ruangan namun juga loyal terhadap institusi sehingg walaupun responden merasa baha pimpinan ruangan kurang baik dalam menjalankan fungsinya 
namun responden tetap mampu menunjukkn perilaku pembuangan sampah tajam dengan baik dan sebanyak $8 \quad(27,6 \%)$ responden perilaku pembuangan sampah tajam kurang baik. Menurut pendapat peneliti pemimpin (kepala ruangan) yang menonjolkan otoritasnya dengan memberikan intruksi tanpa memperhatikan ide dan pendapat bawahan seperti gaya kepemimpinan otoriter, tidak akan meningkatkan motivasi bawahan, karena cenderung terlalu mengatur. Demikian halnya bila pemimpin (kepala ruangan) hanya tergantung pada bawahan, dimana setiap tindakan selalu melibatkan bawahan seperti pada gaya kepemimpinan demokratis akan menyebabkan proses pengambilan keputusan menjadi lambat. Hal ini kurang tepat diterapkan di rumah sakit, karena dalam situasi menangai pasien yang kritis diperlukan tindakan cepat dalam mengambil suatu keputusan.

Pada kepemimpinan yang kurang baik namun perilaku pembuangan sampah tajam pegawainya baik, menurut pendapat peneliti terjadi karena pegawai telah memahami tugas, fungsi dan kedudukannya dengan baik. Pekerjaan sebagai tenaga perawatan berkaitan erat dengan ketrampilan dan keahlian individu, serta kemampuan bekerja sama dengan rekan sejawat yang setara dalam tim. Dengan demikian masih sangat dimungkinkan meskipun kepemimpinan kurang baik namun perilaku pembuangan sampah tajam staff dibawahnya berkategori baik. Berdasarkan penelitian ini, bahwa pemimpin yang baik adalah pemimpin yang dapat memadukan antara gaya kepemimpinan otoriter dengan demokratis seperti pada gaya kepemimpinan partisipatif. Bawahan memerlukan pengawasan yang ketat dengan memberikan intruksi dalam situasi yang darurat dan sangat perlu dilibatkan dalam pengambilan keputusan. Situasi yang demikian nampak meningkatkan kedisiplinan dan perilaku pembuangan sampah tajam kerja bawahan.

\section{KESIMPULAN}

1. Diketahui dari 57 responden dengan perilaku pembuangan sampah tajam, sebanyak 31 $(54,4 \%)$ responden yang tidak baik dan sebanyak 26 (45,6\%) responden yang baik.

2. Diketahui dari 57 responden dengan motivasi, sebanyak 34 (59,6\%) responden motivasi kurang kuat dan sebanyak 23 $(40,4 \%)$ responden motivasi kuat.

3. Diketahui dari 57 responden dengan gaya kepemimpinan, sebanyak 29 (50,9\%) responden gaya kepemimpinan kurang baik dan sebanyak $28 \quad(49,1 \%)$ responden gaya kepemimpinan baik.

4. Ada hubungan motivasi dengan perilaku perawat dalam pembuangan sampah medis benda tajam di RSUD Dr. A. Dadi Tjokrodipo Kota Bandar Lampung tahun 2019 ( $p$-value = 0,000 OR 11,700)

5. Ada hubungan gaya kepemimpinan dengan perilaku perawat dalam pembuangan sampah medis benda tajam di RSUD Dr. A. Dadi Tjokrodipo Kota Bandar Lampung tahun $2019(p$-value $=0,012$ OR 4,725)

\section{DAFTAR PUSTAKA}

Azwar, S. (2016). Sikap Manusia Teori dan Pengukurannya, Edisi ke-2. Yogyakarta: Pustaka Pelajar Offset.

Depkes R. I. (2016). Profil Kesehatan Indonesia. Diakses 
dari http://www. depkes. go.id/resources/.../profil-

kesehatan.../Profil-

Kesehatan-Indonesia2016.pdf.

DepKes, R. I. (2014). Profil Kesehatan Indonesia 2012. Tersedia: http://www. depkes. go. id/resources/d ownload /pusdatin /profilkesehatanindonesia /profilkesehatanindonesia-2014. pdf (Diakses: tanggal 20 Maret 2016).

Fahriyah, L., Husaini, H., \& Fadillah, N. A. (2017). Pengetahuan dan Sikap dengan Perilaku Perawat dalam Pemilahan dan Pewadahan Limbah Medis Padat. Jurnal Publikasi Kesehatan Masyarakat Indonesia, 3(3).

Haeranti, M., \& Dasong, Z. (2018). Hubungan Gaya Kepemimpinan Kepala Ruangan Dengan Kinerja Perawat Pelaksana Di Ruang Rawat Inap Rumah Sakit Umum Daerah Polewali Mandar. Journal of Islamic Nursing, 1(2), 41-50.

Harahap, S. P. D. (2018). Gambaran Perilaku Perawat dalam Membuang Limbah Medis dan Non Medis di Rumah Sakit Bhayangkara TK II Medan Tahun 2017.

Indonesia, P. R. (2015). Peraturan Presiden Republik Indonesia No. 16 Tahun 2015 tentang Kementerian Lingkungan Hidup dan

Kehutanan. Jakarta, Indonesia.

Indonesia, R. (2008). UndangUndang No. 18 Tahun 2008 tentang

Sampah. Jakarta.

KeMenKes, R. I. (2004). Kepmenkes RI No. 1204/Menkes. SK/X/2004 Tentang Persyaratan Kesehatan Lingkungan Rumah Sakit.

KemenKes, R. I. (2016). Profil kesehatan Indonesia tahun 2015. Jakarta: Kementerian Kesehatan Republik Indonesia.

Khodijah, N. (2014). Psikologi Pendidikan. Jakarta: Rajawali Pers.

Lombogia, A., Rottie, J., dan Karundeng, M. (2016). Hubungan Perilaku Dengan Kemampuan Perawat Dalam Melaksanakan Keselamatan Pasien (Patient Safety) Di Ruang Akut Instalasi Gawat Darurat RSUP Prof. Dr. RD Kandou Manado. Jurnal Keperawatan, 4(2).

Mangkunegara, A. A. P. (2003). Manajemen sumber daya manusia perusahaan. Remaja Rosdakarya.

Mayasari, P. (2016). Pengetahuan Dan Keterampilan Perawat Dalam Membuang Limbah Di RSUD Dr. Zainoel Abidin Banda Aceh. Jurnal IImiah Mahasiswa Fakultas Keperawatan, 1(1).

Notoatmodjo, S. (2012). Ilmu Perilaku Kesehatan. Jakarta: Rineka Cipta.

Nurharyanti, L., Ns, E. T. N., Susilaningsih, E. Z., dan Kp, S. (2016). Hubungan antara tingkat pengetahuan perawat dengan perilaku perawat dalam pengelolaan sampah 
medis di ruang rawat inap RSUD Sukoharjo (Doctoral dissertation, Universitas Muhammadiyah Surakarta)

Nursalam. (2016). Manajemen Keperawatan. Jakarta: Salemba Medika.

Ramadhan, A. A., Rahmadi, A. R., dan Djuhaeni, H. (2015). Ability and Willingness to Pay Premium in the Framework of National Health Insurance System. Althea Medical Journal, 2(4), 502-505.

Ridwan, L. F. (2013). Pengaruh Motivasi Intrinsik dan Motivasi Ekstrinsik Terhadap Kinerja Perawat Suatu Kajian Literatur. Bandung: Universitas Padjajaran.

Sari, M. T. (2009). Hubungan budaya organisasi dan gaya kepemimpinan kepala ruangan dengan kinerja perawat pelaksana di ruang rawat inap Rumah Sakit Daerah Raden Mattaher Jambi (Doctoral dissertation, Universitas Indonesia. Fakultas Ilmu Keperawatan).

Simarmata, H. L. T. (2011). Analisis Pengelolaan Limbah Padat dan Cair di RSUD dr.
Djasamen Saragih

Pematangsiantar Tahun 2011.

Sunny, M. P. (2018). Pentingnya Penerapan Etika Kepemimpinan Hindu di Bali Berlandaskan Asta Brata dengan Berbasis Tri Hita Karana. VIDYA WERTTA: Media Komunikasi Universitas Hindu Indonesia, 1(2), 84-93.

WHO. (2016). Health-care waste. https: / /www.who.int/newsroom/factsheets/detail/health-carewaste

WHO. (2017). WHO Global Infection Prevention and Control Network meeting. https: / / www. who.int/infecti on-prevention/about/GIPCNmeeting-feb2017.pdf?ua=1

Wibowo. (2014). Manajemen Kinerja. Jakarta: PT. Rajagrafindo Persada.

Zainaro, M. A., Isnainy, U. C. A. S., Furqoni, P. D., dan Wati, K. (2017). Pengaruh Motivasi Kerja Terhadap Kinerja Perawat Pelaksana Di Ruang Rawat Inap Rumah Sakit Umum Daerah Alimuddin Umar Kabupaten Lampung Barat Tahun 2017. Holistik Jurnal Kesehatan, 11(4), 209215. 